\title{
Immunocytochemical Analysis of $\alpha$-Tubulin Distribution Before and After Rapid Axopodial Contraction in the Centrohelid Raphidocystis contractilis
}

\author{
Risa IKEDA ${ }^{1,2}$, Miki KUROKAWA ${ }^{1}$, Momoka MURAI ${ }^{1}$, Noboru SAITO², Motonori ANDO ${ }^{1,2}$ \\ ${ }^{1}$ Laboratory of Cell Physiology, Department of Science Education, Graduate School of Education, Okayama University, Okayama \\ 700-8530, Japan \\ ${ }^{2}$ Laboratory of Animal Physiology and Pharmacology, Department of Animal Science, Graduate School of Environmental and Life \\ Science, Okayama University, Okayama 700-8530, Japan
}

\begin{abstract}
The centrohelid Raphidocystis contractilis is a heliozoan that has many radiating axopodia, each containing a bundle of microtubules. Although the rapid contraction of the axopodia at nearly a video rate (30 frames/s) is induced by mechanical stimuli, the mechanism underlying this phenomenon in $R$. contractilis has not yet been elucidated. In the present study, we described for the first time an adequate immunocytochemical fixation procedure for $R$. contractilis and the cellular distribution of $\alpha$-tubulin before and after rapid axopodial contraction. We developed a flow-through chamber equipped with a micro-syringe pump that allowed the test solution to be injected at a flow rate below the threshold required to induce rapid axopodial contraction. Next, we used this injection method for evaluating the effects of different combinations of two fixatives (paraformaldehyde or glutaraldehyde) and two buffers (phosphate buffer or PHEM) on the morphological structure of the axopodia. A low concentration of glutaraldehyde in PHEM was identified as an adequate fixative for immunocytochemistry. The distribution of $\alpha$-tubulin before and after rapid axopodial contraction was examined using immunocytochemistry and confocal laser scanning fluorescence microscopy. Positive signals were initially detected along the extended axopodia from the tips to the bases and were distributed in a non-uniform manner within the axopodia. Conversely, after the induction of a rapid axopodial contraction, these positive signals accumulated in the peripheral region of the cell. These results indicated that axopodial microtubules disassemble into fragments and/ or tubulin subunits during rapid axopodial contraction. Therefore, we hypothesize that the mechanism of extremely rapid axopodial contraction accompanied by cytoskeletal microtubule degradation in $R$. contractilis involves microtubule-severing at multiple sites.
\end{abstract}

Keywords: heliozoa, immunocytochemistry, microtubule, glutaraldehyde, confocal microscopy.

\section{INTRODUCTION}

Heliozoa are characterized by a high number of radiating axopodia, with each axopodia containing a bun-

Address for correspondence: Motonori Ando, Laboratory of Cell Physiology, Department of Science Education, Graduate School of Education, Okayama University, Okayama 700-8530, Japan; Fax: +81 86251 7755; E-mail: andom@okayama-u.ac.jp dle of axonemal microtubules as a cytoskeletal element. These axopodia have several physiological functions, including environmental stimulus recognition, cell locomotion, and food capture, which are mediated by the change in the axopodial length via the assembly and disassembly of microtubules (Watters 1968, Suzaki et al. 1980, Sakaguchi and Suzaki 2002, Khan et al. 2006). Axopodia are distinctively sensitive to a variety of physical stimuli, such as mechanical or electrical 
shocks, ultrasound, cold temperatures, high pressure, and chemicals (Febvre-Chevalier and Febvre 1993, 2001). These axopodia rapidly contract upon adequate stimulation. For example, actinophryid and centrohelid heliozoa exhibit rapid axopodial contraction at nearly a video rate $(33 \mathrm{msec})$ (Ockleford and Tucker 1973, Bardele 1975, Suzaki et al. 1980, Kinoshita et al. 1995).

Morphological and physiological differences are observed during axopodial contraction between actinophryids and centrohelids. Actinophryids, such as Echinosphaerium nucleofilum and Actinophrys sol, show the double-helical arrangement of microtubules inside each axopodium (Ockleford and Tucker 1973, Suzaki et al. 1994). Both $A$. sol and E. nucleofilum exhibit rapid contraction of the axopodium in response to contact with a prey (Ockleford and Tucker 1973, Suzaki et al. 1994). The axopodial microtubules in actinophryids originate from the nuclear envelope (FebvreChevalier and Febvre 1993, 2001). In A. sol, the length of an axopodium rapidly decreases to approximately $20-50 \%$ of the initial length in response to contact with a prey (Ockleford and Tucker 1973, Kinoshita et al. 2001). In contrast, centrohelids, such as Raphidocystis contractilis, which was initially described as Raphidiophrys contractilis but was later transferred to the genus Raphidocystis (Zlatogursky et al. 2018), and Heterophrys marina, show the hexagonal arrangement of microtubules inside each axopodium (Bardele 1975, Kinoshita et al. 1995). Both $R$. contractilis and $H$. marina exhibit rapid axopodial contraction induced by simple mechanical stimulation (e.g., tapping the microscope stage) (Bardele 1975, Khan et al. 2003). The axopodial microtubules in centrohelids originate from the centroplast, which serves as the microtubuleorganizing center (Febvre-Chevalier and Febvre 1993, 2001). In $R$. contractilis, all axopodia immediately and synchronously retracted into the cell body in response to mechanical stimulation (Khan et al. 2003). These observations suggested that the mechanisms underlying rapid axopodial contraction in centrohelids likely differ from those in actinophryids.

Actinophryids and centrohelids exhibit the abovementioned distinct differences in the manners of rapid axopodial contraction, respectively. Possible mechanisms in actinophryids have been proposed until now (Matsuoka et al. 1985, Ando and Shigenaka 1989, Kinoshita et al. 2001). These reports indicate that the distal parts of microtubule bundles moved to the proximal regions of the axopodia during rapid contraction in those actinophryids, and that the contractile tubules that run parallel to the microtubules may provide the motivating force for inducing axopodial retraction. Conversely, few studies have evaluated the morphological features of rapid axopodial contraction in $R$. contractilis. Even though a previous report has described the ultrastructure and axopodial contraction of $R$. contractilis, a forceproducing structure, such as the contractile tubules in actinophryids, has not yet been identified (Khan et al. 2003). Moreover, the morphological changes that occur in $R$. contractilis during rapid contraction and its underlying mechanism remain unclear.

To reveal the changes occurring in microtubule formation in the axopodia during rapid contraction at the whole-cell level, we attempted to use immunofluorescence microscopy for comparing the cellular distribution of $\alpha$-tubulin before and after axopodial contraction. However, our preliminary study revealed two problems associated with observing the cells before the induction of rapid axopodial contraction. The first problem involved the method of fixation using a micropipette. The act of injecting fixative provides a direct physical stimulus; thus, it induces a rapid axopodial contraction in $R$. contractilis. For reducing the mechanical stimulation induced by fixative injection, we needed to identify a method of injecting test solutions that remained under the threshold required to induce rapid contraction. The second problem involved the fixative used to prepare specimens for immunocytochemistry. Cell preparation with paraformaldehyde-based fixative, the most commonly used reagent for immunocytochemistry, could not preserve the axopodial length.

In this study, we developed a method of fixative injection that would aid in maintaining the original length of the $R$. contractilis axopodia and explored adequate fixatives for immunocytochemistry. We analyzed the distribution of $\alpha$-tubulin before and after rapid axopodial contraction using laser confocal immunofluorescence microscopy. To the best of our knowledge, ours is the first report of an immunocytochemical analysis and distribution of $\alpha$-tubulin in cells from a heliozoan species before and after rapid axopodial contraction.

\section{MATERIALS AND METHODS}

\section{Organisms and conventional culture}

The centrohelid heliozoan $R$. contractilis was monoxenically cultured at $20 \pm 1{ }^{\circ} \mathrm{C}$ in a culture medium based on $10 \%$ artificial seawater (46.2 mM NaCl, $0.9 \mathrm{mM} \mathrm{KCl}, 0.8 \mathrm{mM} \mathrm{CaCl}_{2}, 2.3$ $\mathrm{mM} \mathrm{MgCl}$, and $0.6 \mathrm{mM} \mathrm{NaHCO}_{3}$ ) supplemented with $0.74 \mathrm{mM}$ 
$\mathrm{CH}_{3} \mathrm{COONa}, 7 \mu \mathrm{M} \mathrm{CaCl}, 0.01 \%$ polypepton, $0.02 \%$ tryptone, $0.02 \%$ yeast extract plus the prey flagellate Chlorogonium capillatum (Kinoshita et al. 1995). The organisms were subcultured at intervals of approximately 7-10 days. Prior to each experiment, $R$. contractilis cells were collected in 2-3 centrifugation steps at 1000 rpm for $5 \mathrm{~min}$ and allowed to rest undisturbed for $30 \mathrm{~min}$ to recover from axopodial disturbances caused by pipetting.

\section{Video microscopy}

Mechanical stimulation was applied by dropping $5 \mu 1$ of culture medium onto the cells to induce rapid axopodial contraction. We observed changes in the axopodial lengths using video microscopy. Video images were obtained using a differential interference contrast microscope (IX71, Olympus, Tokyo, Japan) equipped with an Olympus DP21 microscope camera at a rate of 25 frames/s.

\section{Electron microscopy}

Conventional electron microscopy was performed to observe the structures associated with axopodial microtubules. The cells were prefixed in a solution containing 3\% glutaraldehyde, 0.02 $\mathrm{mM} \mathrm{MgSO}, 2 \mathrm{mM}$ sucrose, $1 \mathrm{mg} / \mathrm{ml}$ ruthenium red, and $50 \mathrm{mM}$ cacodylate buffer for $30 \mathrm{~s}$ at room temperature. Next, the cells were mixed with an equal volume of post-fixative solution containing $0.5 \% \mathrm{OsO}_{4}$ in $50 \mathrm{mM}$ cacodylate buffer for $30 \mathrm{~min}$ at room temperature. The fixed cells were rinsed with washing buffer, embedded in $1 \%$ low melting point agarose (Nacalai Tesque, Kyoto, Japan), dehydrated through a graded ethanol series, and embedded in Spurr's resin. Lastly, all sections were stained with uranyl acetate and lead citrate and examined using a transmission electron microscope $(\mathrm{H}-$ 7650 , Hitachi, Tokyo, Japan) at $80 \mathrm{kV}$.

\section{Light microscopy}

Fixatives containing $8 \%$ paraformaldehyde or $0.4 \%$ glutaraldehyde were prepared. The fixatives were buffered in phosphate buffer ( $\mathrm{pH}$ 7.4) or microtubule stabilization buffer (PHEM buffer; $60 \mathrm{mM}$ PIPES, $25 \mathrm{mM}$ HEPES, $10 \mathrm{mM}$ EGTA, 4 mM MgSO,$~ p H$ 6.9) (Schliwa and van Blerkom 1981, Waters et al. 1998). An equal volume of the fixative was added to the cell suspension. The final concentrations of the aldehydes (4\% paraformaldehyde and $0.2 \%$ glutaraldehyde) were similar to those conventionally used for immunocytochemistry (Griffiths 2012, Karabay and Ayşegül 2012). The cells were fixed with each fixative for $10 \mathrm{~min}$ at room temperature. The fixed cells were then rinsed with PBS. Lastly, the cells were observed using a differential interference contrast microscope.

\section{Immunocytochemistry and confocal microscopy}

Cells were fixed with $4 \%$ paraformaldehyde or $0.2 \%$ glutaraldehyde in PHEM in the presence or absence of mechanical stimulation. Cells not induced to undergo axopodial contraction were fixed by gently injecting a fixative via a micro flow-through chamber. Cells induced to undergo axopodial contraction were subjected to mechanical stimulation prior to the addition of fixative. The fixed cells were then subjected to three 5-min rinses with PBS. Subsequently, the cells were embedded in $1 \%$ low melting point agarose to prevent damage to the cells during subsequent procedures. After cooling at $4^{\circ} \mathrm{C}$ for $15 \mathrm{~min}$, the cells were permeabilized with $0.1 \%$ Triton X-100 in PBS for 15 min. Next, the cells were blocked with $1 \%$ goat serum in PBS for 30 min, incubated with a mouse antibody against $\alpha$-tubulin (clone DM1A; Thermo Fisher Scientific, Tokyo, Japan; dilution, 1:200) in PBS for $1 \mathrm{~h}$ at room temperature, and rinsed with PBS. After washing, the cells were incubated with a goat anti-mouse Alexa Fluor 488-conjugated secondary antibody (A-11001; Thermo Fisher Scientific, Tokyo, Japan; dilution, 1:200) for $1 \mathrm{~h}$ at room temperature. Lastly, the TrueView autofluorescence quenching kit (Vector Laboratories, Burlingame, CA, USA) was used to quench cellular autofluorescence. The cells were analyzed using a confocal laser scanning microscope system (FV1200, Olympus, Japan) with a $60 \times$ silicon objective, and the image size was set at $1024 \times 1024$ or $256 \times 3072$ pixels. The scan rate was $12.5 \mu \mathrm{s} /$ pixel, and the step size ranged from 0.05 to $0.5 \mu \mathrm{m}$. The z-axis was set along the axopodial microtubules from the bottom to the top.

\section{RESULTS}

\section{Morphological characteristics of $R$. contractilis}

Rapid axopodial contraction in $R$. contractilis was examined using video microscopy (Fig. 1). R. contractilis has a spherical cell body surrounded by several radiating axopodia (Fig. 1A). These axopodia have an average length of $60 \mu \mathrm{m}$ and a maximum length exceeding $100 \mu \mathrm{m}$. Each axopodium contains granular kinetocysts that participate in food capture (Fig. 1A, arrowheads). Immediately after mechanical stimulation (see Methods), all axopodia retracted into the cell body at a less-than-video rate. The axopodial length was reduced to less than $10 \%$ of the initial length immediately after axopodial contraction (Fig. 1B). Simultaneously, the widths of the contracted axopodia appeared to increase compared with the widths before the onset of contraction (Fig. 1B, arrow). The microtubule orientation in the central and peripheral regions of the cells after rapid axopodial contraction was examined using conventional electron microscopy (Fig. 2). The centroplast, a microtubule-organizing center presenting in the centrohelid heliozoa located at the center of each cell (Fig. 2A). A cross-sectional analysis revealed that each axopodium comprised six microtubules in the peripheral region of the cell (Fig. 2B).

\section{Evaluation of fixation procedures}

Next, we investigated the dependence of flow rate on the rapid axopodial contraction in $R$. contractilis using a micro flow-through chamber. This chamber, equipped with a micro-syringe pump, was expected to mitigate the effect of shear stress against adherent cells during the injection of test solutions (Fig. 3). We examined the effect of the flow rate on the rapid axopodial contraction by changing the flow rate from 0.5 to 500 

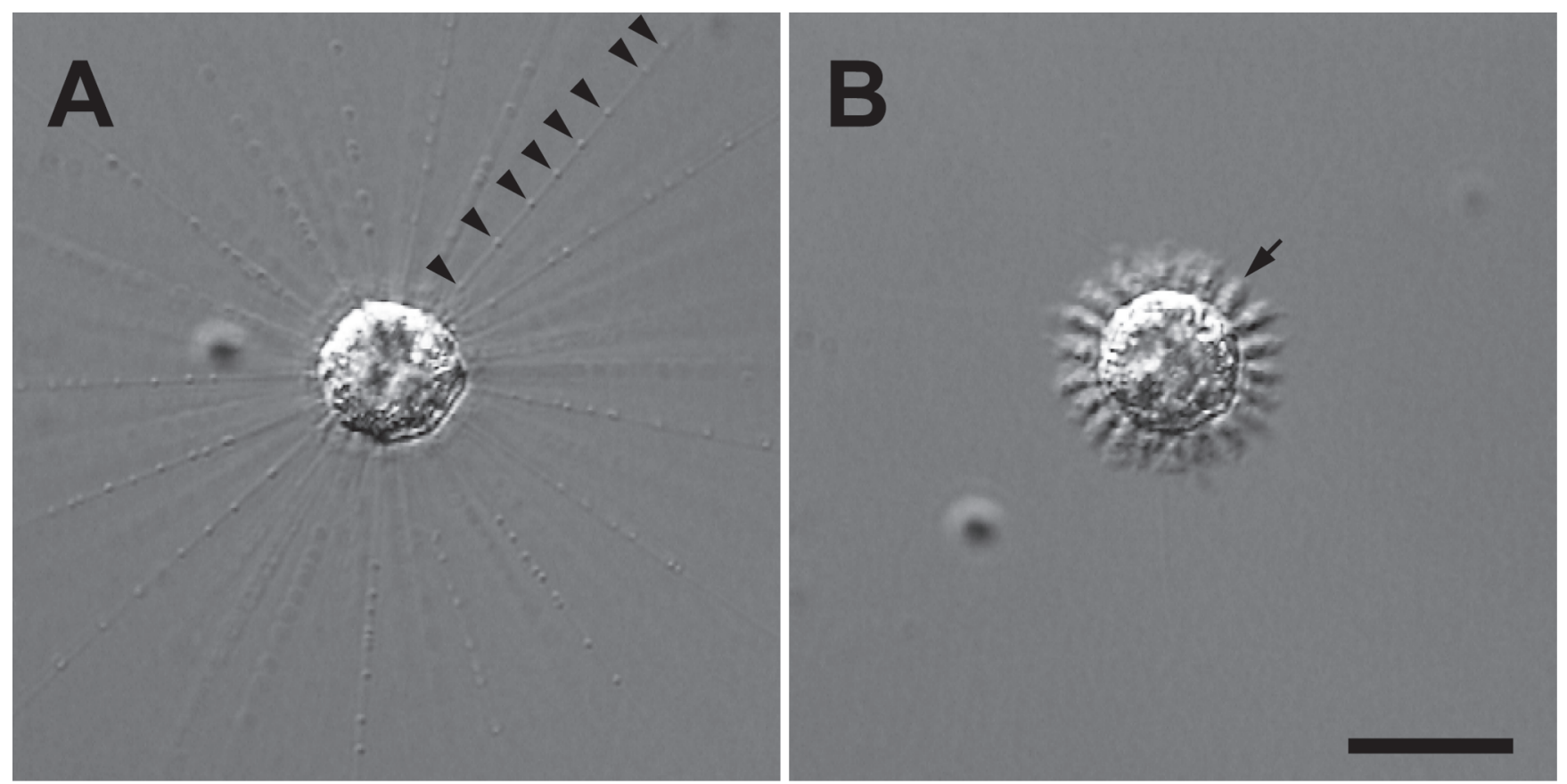

Fig. 1. (A, B) Rapid axopodial contraction induced by mechanical stimulation in R. contractilis. Images (A) before and (B) after rapid axopodial contraction. Arrowheads indicate kinetocysts. Note the synchronized retraction of all axopodia and the apparent increases in the widths of contracted axopodia relative to the features observed before the onset of axopodial contraction (an arrow). Scale bar: $20 \mu \mathrm{m}(\mathrm{A}, \mathrm{B}$ ).
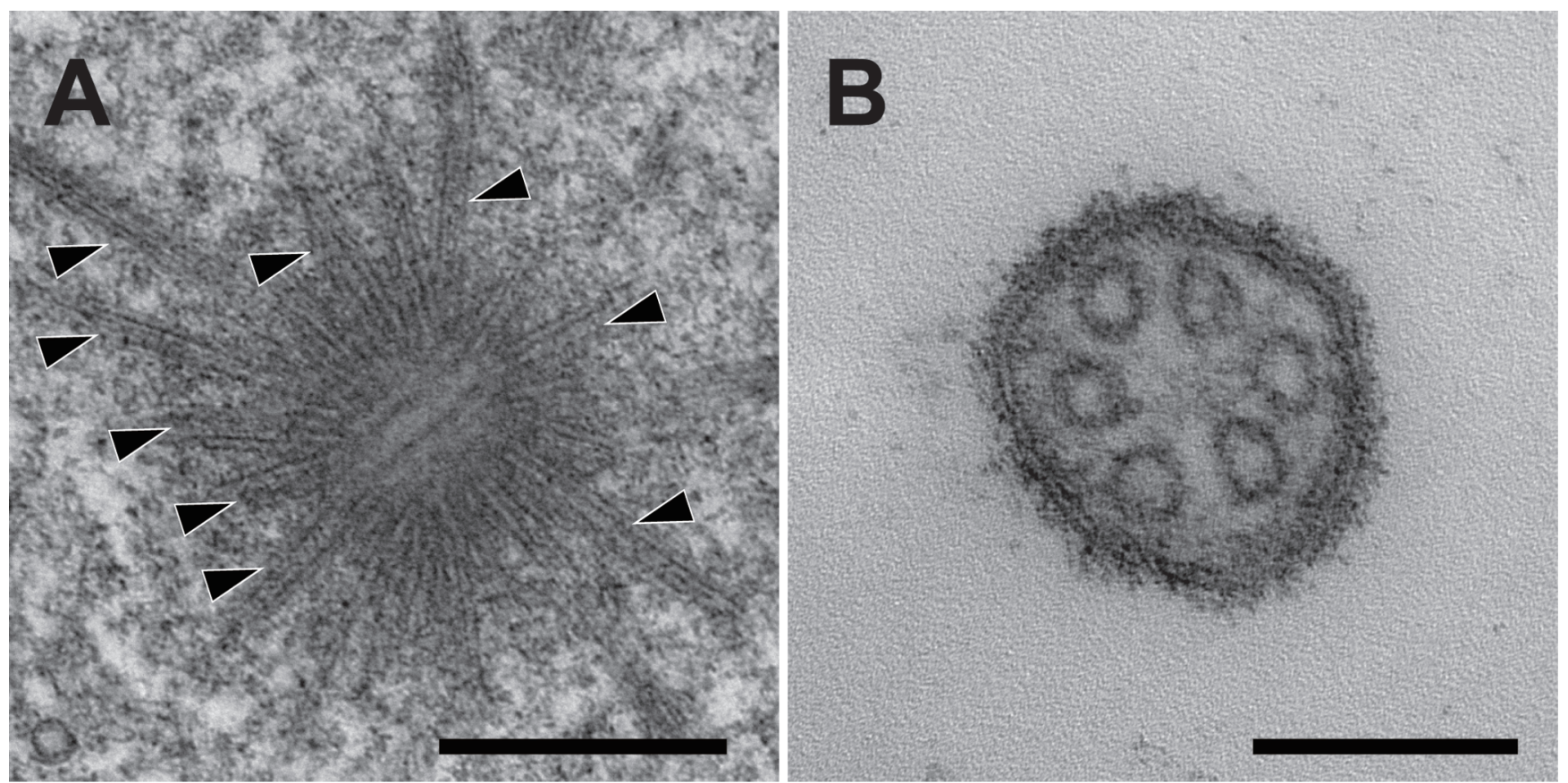

Fig. 2. (A, B) Fine structures associated with axopodial microtubules. (A) Centroplast in the center of the cell. (B) Cross-section of an axopodium in the peripheral region of the cell. Note that bundles of microtubules radiate from the centroplast (arrowheads) and that the axopodium comprises six microtubules. Scale bars: $500 \mathrm{~nm}$ (A), $100 \mathrm{~nm}$ (B). 


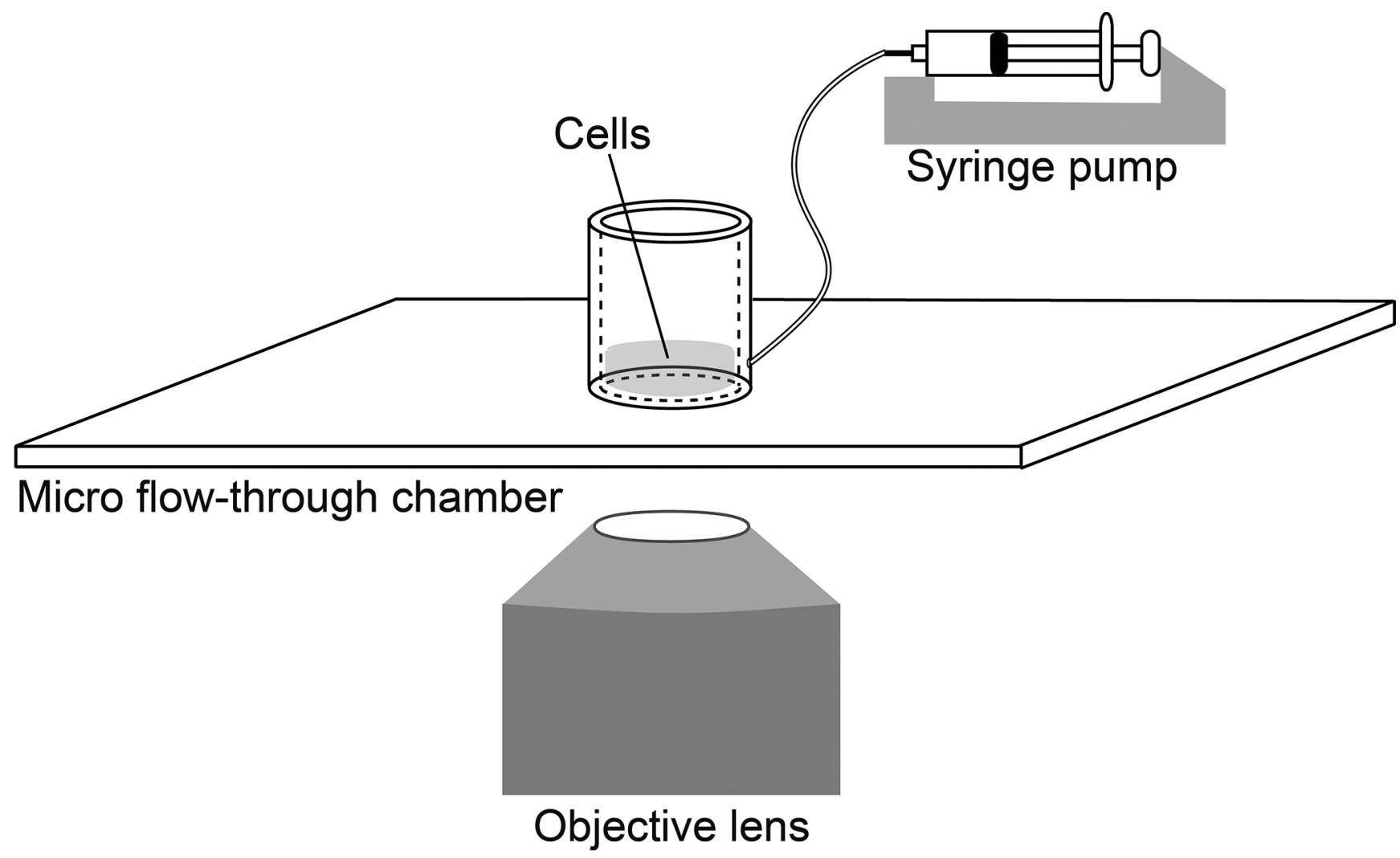

Fig. 3. Schematic illustration of the experimental setup. The fixative is injected into the cell suspension via a micro flow-through chamber with a syringe pump. Next, the cells are fixed by injecting the fixative at a rate below the threshold required for inducing rapid contraction. The cells are then observed under a microscope.

$\mu \mathrm{l} / \mathrm{min}$. Notably, gentle perfusion with culture medium at a flow rate of $<50 \mu \mathrm{l} / \mathrm{min}$ did not evoke rapid axopodial contraction. Therefore, in subsequent experiments, the test solutions were injected into the cell chamber at a flow rate of $12.5 \mu 1 / \mathrm{min}$.

Next, the effects of fixatives on the morphological appearances of the axopodia were examined using light microscopy (Fig. 4). The cells were fixed in solutions containing $4 \%$ paraformaldehyde or $0.2 \%$ glutaraldehyde in phosphate buffer or PHEM. Initially, the cells were fixed with $4 \%$ paraformaldehyde in phosphate buffer. Despite the status of this fixative as the most widely used in immunohistochemical applications, we found that $4 \%$ paraformaldehyde caused a reduction in the lengths of axopodia compared with the original lengths before fixation (Fig. 4A). A similar result was obtained when the cells were fixed with $4 \%$ paraformaldehyde in PHEM (Fig. 4B), and fluorescence images of $\alpha$-tubulin labeling revealed the breakdown of axopodial microtubules within the contracted axopodia (data not shown). Second, the cells were fixed using $0.2 \%$ glutaraldehyde. The axopodial lengths were not maintained when the cells were fixed with $0.2 \%$ glutaraldehyde in phosphate buffer (Fig. 4C). Conversely, the axopodial lengths were maintained when the cells were fixed with $0.2 \%$ glutaraldehyde in PHEM (Fig. 4D).

\section{Distribution of $\alpha$-tubulin before and after rapid axo- podial contraction}

The cellular distribution of $\alpha$-tubulin before and after rapid axopodial contraction was examined using confocal microscopy. The cells were fixed using $0.2 \%$ glutaraldehyde in PHEM. Positive signals corresponding to $\alpha$-tubulin were detected along the fully extended axopodia in the absence of induced axopodial contraction (Fig. 5A). Notably, the positive signals radiated from the centroplast (Fig. 5B). A detailed observation of the extended axopodia in the equatorial plane of the cell revealed that the positive signals often appeared to be discontinuously distributed along the axopodia (Fig. 6). 

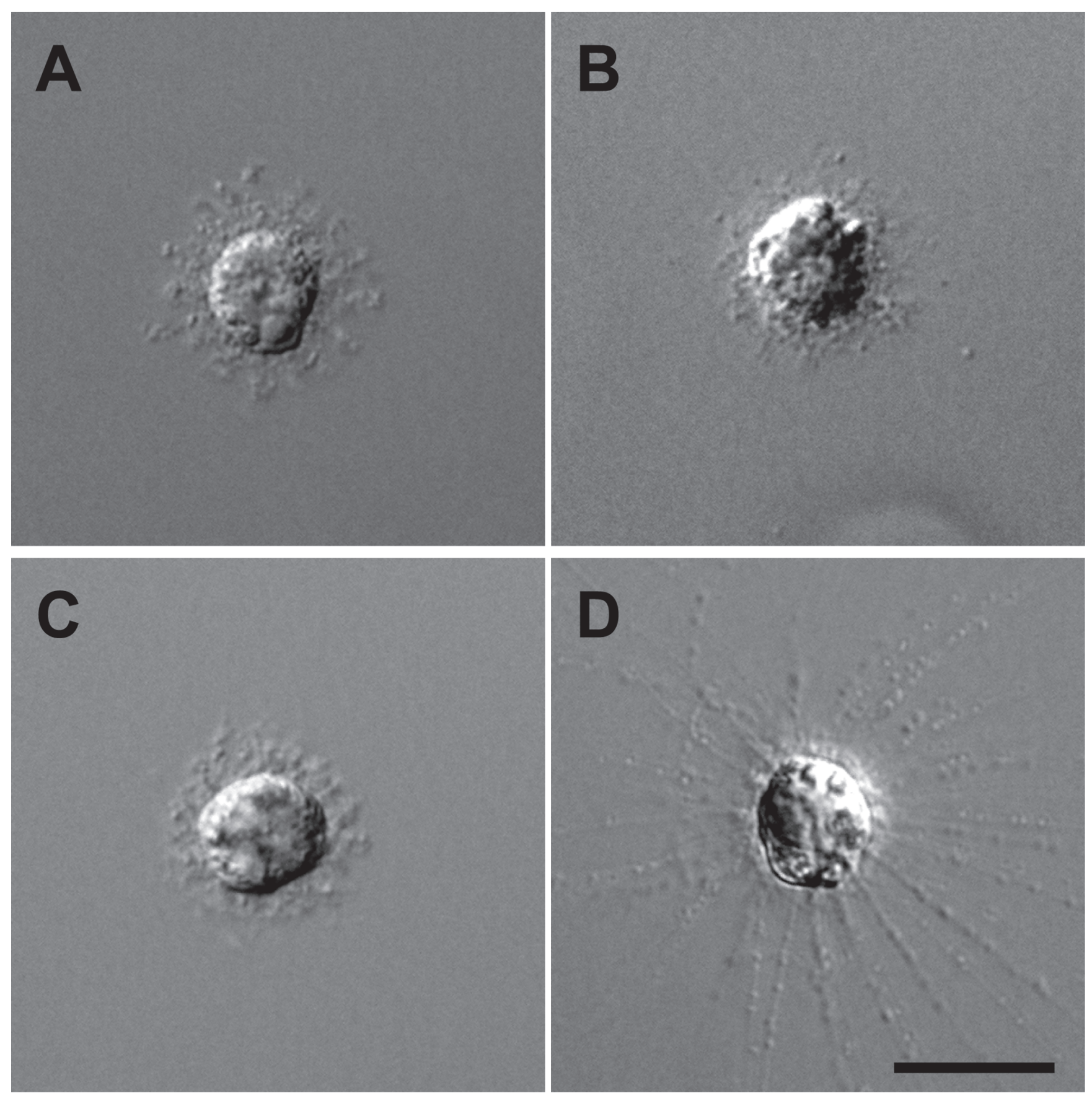

Fig. 4. (A-D) Evaluation of the maintenance of the original lengths of axopodia in $R$. contractilis using different combinations of fixative and buffer. Cells were fixed with (A) $4 \%$ paraformaldehyde in phosphate buffer, (B) $4 \%$ paraformaldehyde in PHEM, (C) $0.2 \%$ glutaraldehyde in phosphate buffer, or (D) $0.2 \%$ glutaraldehyde in PHEM. Note that only fixation with $0.2 \%$ glutaraldehyde in PHEM maintained the axopodial length. Scale bar: $20 \mu \mathrm{m}$. 


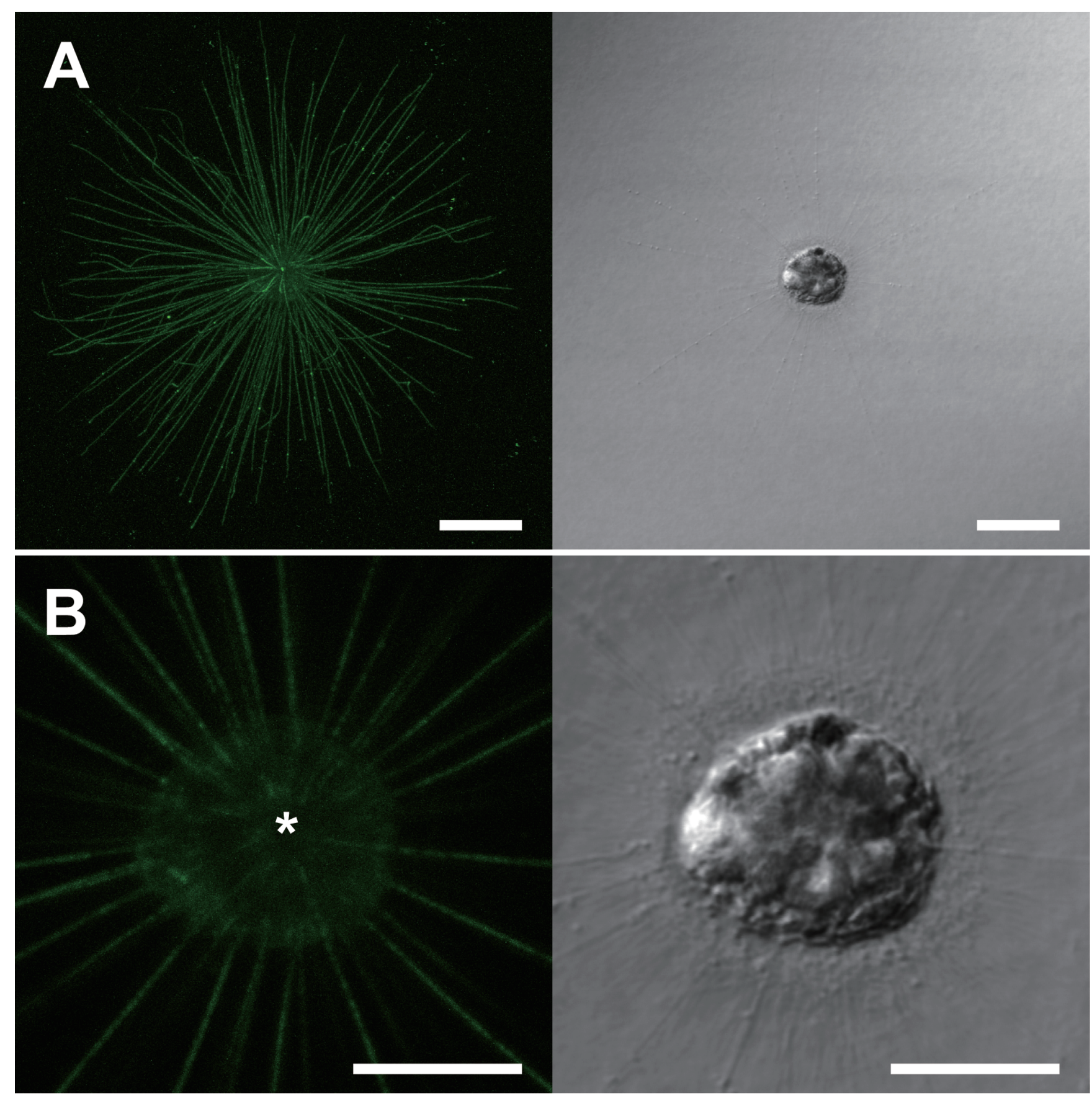

Fig. 5. (A, B) The distribution of $\alpha$-tubulin in the cell before rapid axopodial contraction. (A) Low-magnification images of a cell without the induction of rapid axopodial contraction. A projection image of the whole cell was constructed from 192 optical sections obtained at 0.5 $\mu \mathrm{m}$ intervals (left); the corresponding light micrograph is also shown (right). (B) High-magnification images of the same cell shown in (A). A projection image of the equatorial plane of the cell body constructed from 5 optical sections taken at $0.5 \mu \mathrm{m}$ intervals, and the corresponding light micrograph. The asterisk indicates a centroplast. Note that positive signals were detected along the fully extended axopodia. Scale bars: $20 \mu \mathrm{m}$ (A), $10 \mu \mathrm{m}$ (B). 


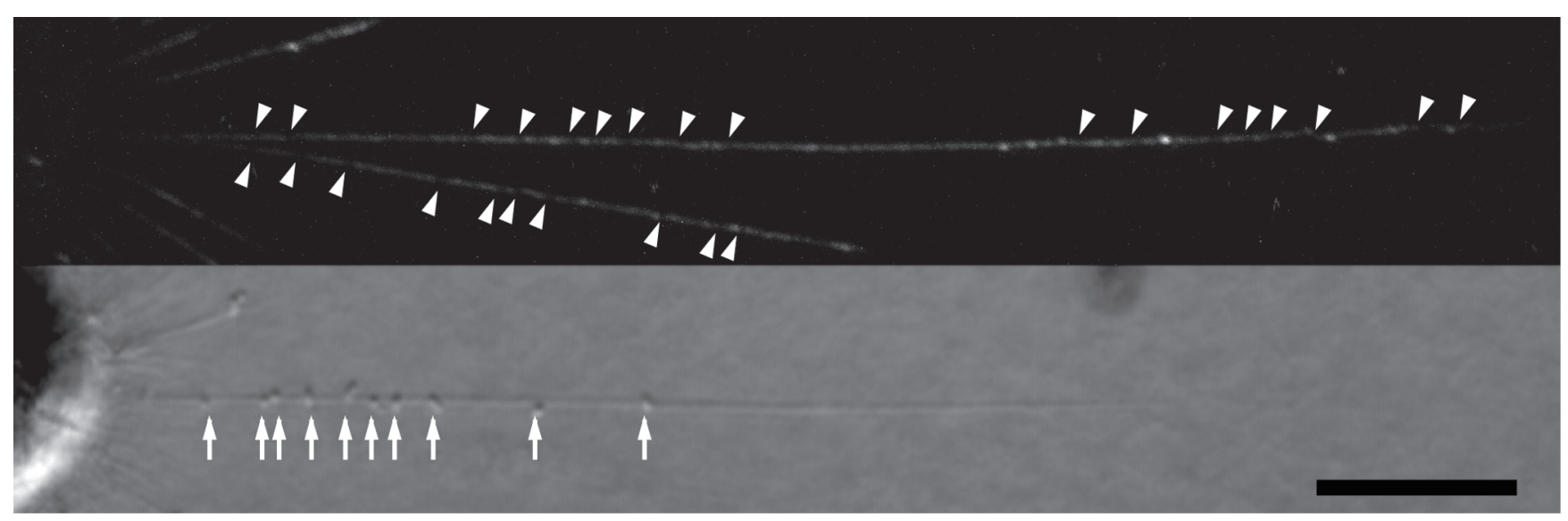

Fig. 6. Confocal analysis of $\alpha$-tubulin-immunolabeled extended axopodia. Fine reconstructed projection image from 161 optical sections taken at a $0.05 \mu \mathrm{m}($ top $)$ and the corresponding light micrograph (bottom). Note the regions of relatively low fluorescence (arrowheads) did not correspond to the location of kinetocysts (arrows). Scale bar: $10 \mu \mathrm{m}$.

Following the induction of axopodial contraction, however, positive signals were detected within the completely contracted axopodia in the cell (Fig. 7A). Those signals accumulated in the peripheral region of the cell (Fig. 7B). Moreover, the signals in the cell with contracted axopodia often exhibited a branched appearance in the distal part of axopodia (Fig. 7B, arrowheads).

\section{DISCUSSION}

\section{Adequate chemical fixation for immunocytochemis- try in $R$. contractilis}

The axopodia in $R$. contractilis are remarkably sensitive to mechanical stimulation, and rapid contraction can be easily induced even by subtle fluid shear stress. Moreover, it is difficult to maintain the axopodial extension during chemical fixation. In this study, we developed a flow-through chamber equipped with a micro-syringe pump that allowed us to inject test solutions at a flow rate below the threshold required for inducing rapid axopodial contraction. This injection method enabled the chemical fixation of cells without inducing the mechanical stimulation required to induce rapid axopodial contraction. Using this method, we evaluated the effects of different combinations of fixatives ( $4 \%$ paraformaldehyde or $0.2 \%$ glutaraldehyde) and buffers (phosphate buffer or PHEM) on the morphological structures of axopodia. Notably, we determined that $0.2 \%$ glutaraldehyde in PHEM was the most suitable fixative for maintaining axopodial extension. Moreo- ver, to the best of our knowledge, this is the first study that obtained successful results in $R$. contractilis cell fixation accompanied by the maintenance of axopodial length due to newly developed fixation procedures. Besides, the developed fixation protocol with the original device allowed us to label cytoskeletal microtubules in the centrohelid extended axopodia using an $\alpha$-tubulin antibody for the first time.

Aldehydes, which are the most frequently used fixatives, stabilize the fine structural details of cells and tissues prior to a light or electron microscopic evaluation (Kiernan 2000). Glutaraldehyde has been widely used for conventional electron microscopy applications, and is usually applied to heliozoa at concentrations of $1-6 \%$ (Tilney et al. 1966, Ockleford and Tucker 1973, Bardele 1975). Formaldehyde is frequently used to fix tissues for immunohistochemical applications, as this chemical appears to be a chemically milder fixative than glutaraldehyde, and thus improves the retention of antigenicity. However, it is difficult to preserve the cytoplasmic microtubules in cultured cells using formaldehyde alone (McBeath and Fujiwara 1984). The low concentrations of glutaraldehyde (e.g., $0.2 \%$ ) have been applied to cytoplasmic microtubules (Gueth-Hallonet et al. 1993, Evangelio et al. 1998, Smith et al. 2004). In our experiments, we explored two types of $\mathrm{pH}$-buffered solutions, phosphate buffer and PHEM. Phosphate buffer is commonly used for chemical fixation and has a stable buffering capacity in the physiological $\mathrm{pH}$ range. However, the lengths of axopodia were not maintained when the cells were fixed using paraformaldehyde or glutaraldehyde in phosphate buffer. In contrast, PHEM has been 


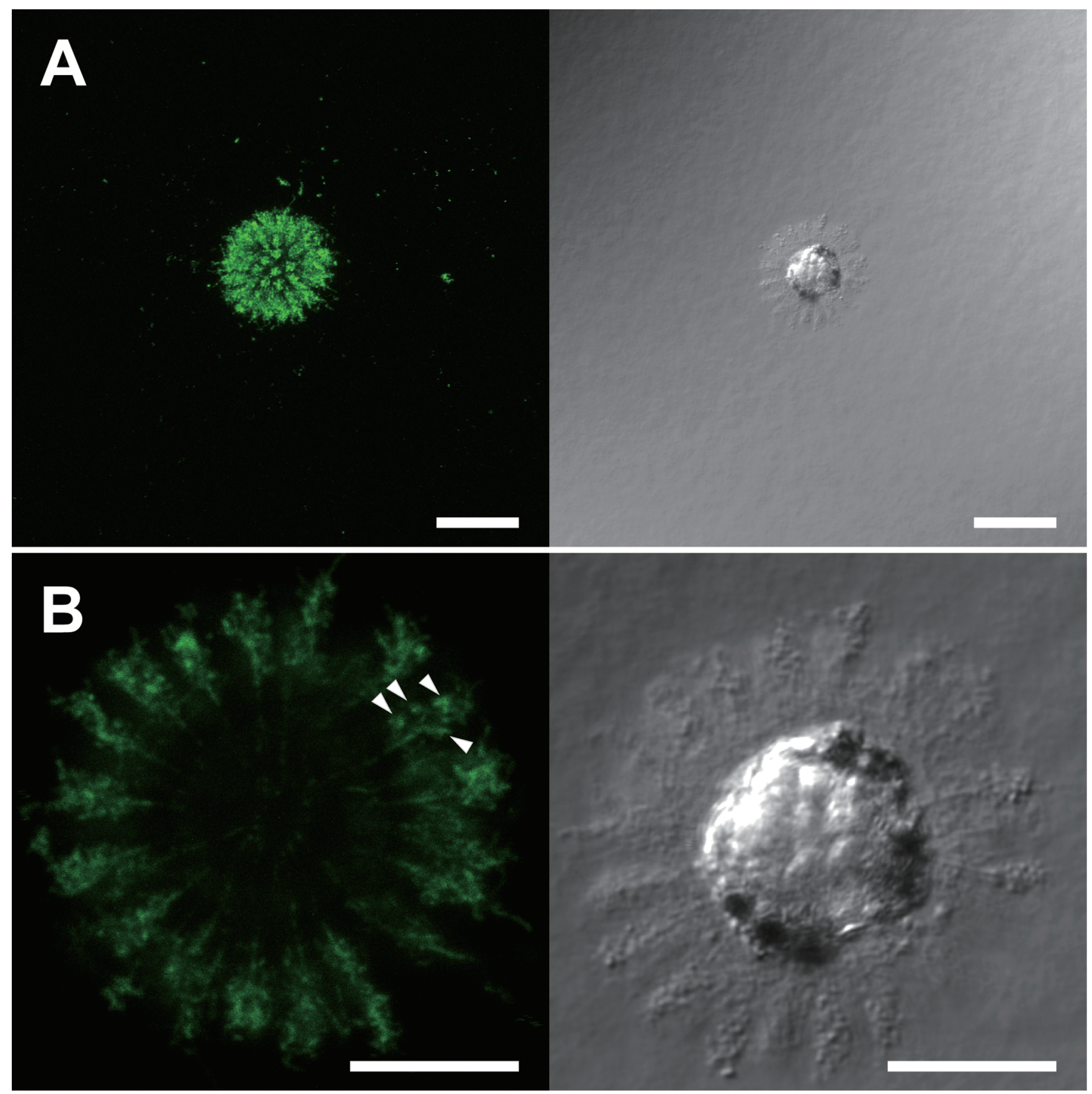

Fig. 7. (A, B) The distribution of $\alpha$-tubulin in the cell after rapid axopodial contraction. (A) Low-magnification images of the cell after the induction of rapid axopodial contraction. A projection image of the whole cell constructed from 87 optical sections taken at a $0.5 \mu \mathrm{m}$ interval (left) and the corresponding light micrograph (right). (B) High-magnification images of the same cell shown in (A). A projection image of the equatorial plane of the cell body constructed from 5 optical sections taken at a $0.5 \mu \mathrm{m}$ interval (left), and the corresponding light micrograph $(r i g h t)$. Note that the positive signals in the distal parts of the axopodia have a branched appearance (arrowheads). Scale bars: $20 \mu \mathrm{m}$ (A), $10 \mu \mathrm{m}$ (B). 
revealed to preserve microtubules during immunostaining applications (Schliwa and Van Blerkom 1981, Allan 1999). PHEM contains components that promote microtubule assembly, as well as EGTA to chelate calcium ions and prevent disassembly. Consequently, the synergistic effects of $0.2 \%$ glutaraldehyde and PHEM enabled the maintenance of the axopodial microtubules in $R$. contractilis.

\section{A possible mechanism of rapid axopodial contrac- tion in $R$. contractilis}

To the best of our knowledge, this is the first report to describe the distribution of $\alpha$-tubulin in heliozoa using immunocytochemistry, and our newly developed method allowed us to label the extended axopodia, including the microtubules, without inducing axopodial contraction. A fine confocal analysis revealed an inho- mogeneous pattern of immunofluorescence along the entire length of the axopodia. Several previous reports of sperm studies indicated that post-translationally modified tubulins may be distributed non-uniformly within the flagella, and the observed staining pattern is believed to reflect the specific masking of the corresponding epitope by post-translational modifications of the microtubule (Prigent et al. 1996, Peknicova et al. 2007). Different post-translational modifications of tubulin have various effects on the functions of microtubules. Namely, the acetylation of tubulin indirectly affects the stability of microtubules, and in neurons, these acetylated microtubules are a preferred substrate of katanin, a microtubule-severing protein (Sudo and Baas 2010). We hypothesize that in the axopodial microtubule, $\alpha$-tubulin undergoes certain post-translational modifications such as phosphorylation, glycosylation, ubiquitination, meth-

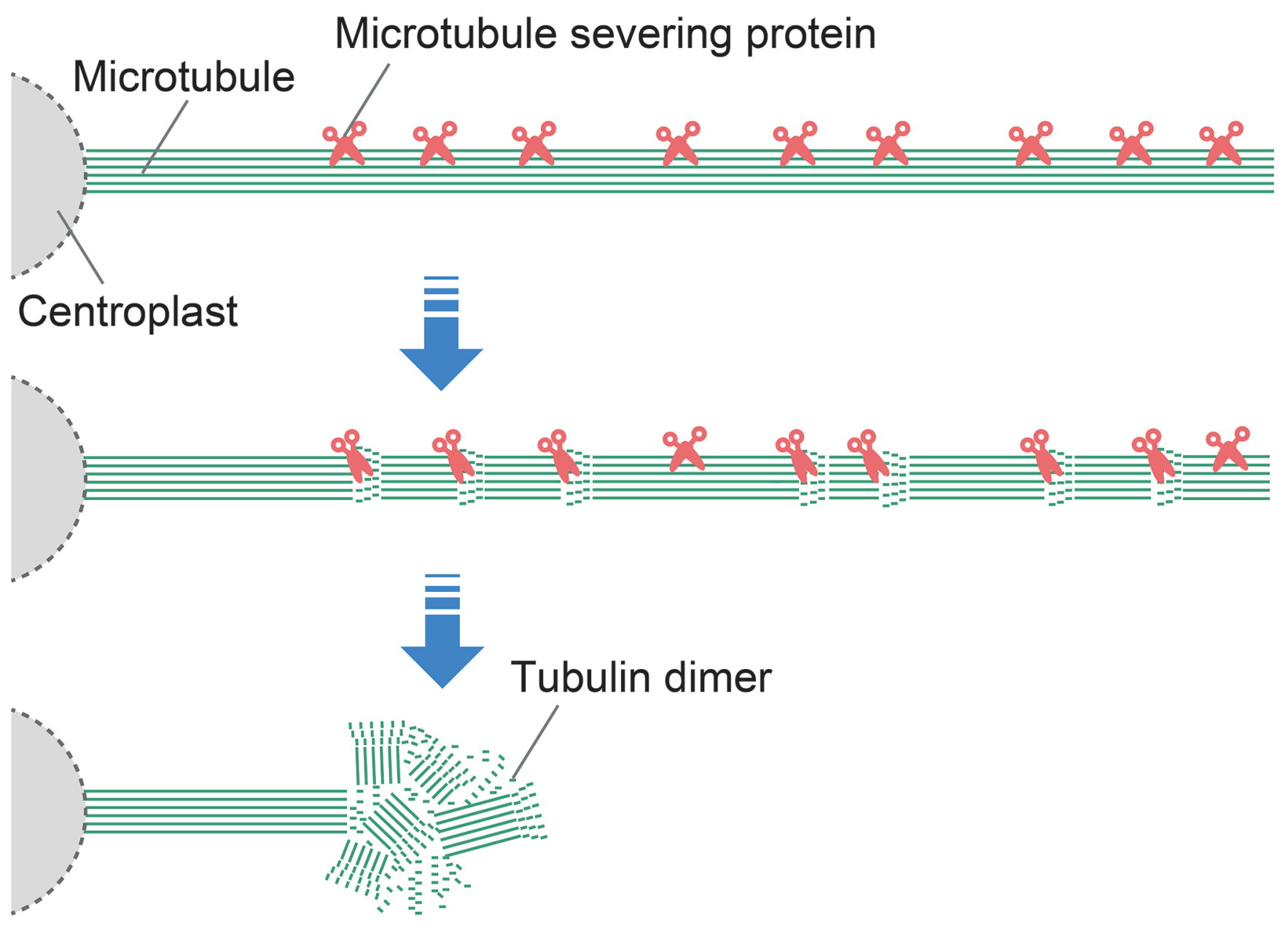

Fig. 8. A schematic diagram illustrating the possible process of rapid axopodial contraction. Here, axopodial microtubules are severed at multiple sites by microtubule severing proteins. Subsequently, the microtubule fragments are depolymerized. Finally, rapid axopodial shortening is completed. 
ylation, and acetylation, which influence the microtubule dynamics in the axopodia of $R$. contractilis. We also speculated that the multiple regions of relatively low fluorescence in the extended axopodia, which were observed in this study, may correspond to the regions of tubulin that are bound and severed by microtubulesevering proteins.

Immunocytochemistry also revealed the accumulation of positive signals in the peripheral region of the cell after rapid axopodial contraction. The results indicated that axopodial microtubules disassemble into fragments and/or tubulin subunits located in the contracted axopodia. In general, the velocity of the microtubule disassembly in animal and plant cells varies from 0.1-3.3 $\mu \mathrm{m} / \mathrm{s}$ (Horio and Hotani 1986, Cassimeris et al. 1988, Belmont et al. 1990, Moore et al. 1997). Axopodial contraction in $R$. contractilis occurred at a rate greater than 250 times that of microtubule disassembly (data not shown). Namely, we cannot explain the rapid degradation of axopodial microtubules during axopodial contraction if the disassembly of microtubules typically originates from the proximal end of the centroplast. On the other hand, the stalked marine gymnosphaerid heliozoan Actinocoryne contractilis also exhibits rapid contraction in response to mechanical stimulation, and the severed and/or fragmented microtubule bundles in the stalk have been found after rapid contraction (Febvre-Chevalier et al. 1986, Febvre-Chevalier and Febvre 1992). Therefore, we propose a model of extremely rapid microtubule degradation at multiple fragmentation sites in $R$. contractilis. A schematic of the possible process of rapid axopodial contraction in $R$. contractilis is shown in Fig. 8. The microtubule-severing process generates a high number of microtubule minus ends and initiates the depolymerization of microtubules at the fragment ends. This process of microtubule breakdown may account for the extremely rapid axopodial contraction in $R$. contractilis.

Further studies are required for revealing the mechanism underlying microtubule dynamics in $R$. contractilis. We must use our newly developed fixative injection procedure and electron microscopy to observe the detailed morphological structure of the axopodial microtubule before rapid axopodial contraction. We should also examine the distribution of $\alpha$-tubulin using immunoelectron microscopy. Moreover, we should explore the post-translational modifications of tubulin using modification-specific antibodies. Presently, we are performing a de novo transcriptome analysis to identify candidate microtubule-severing genes.
Acknowledgment. This study was supported by a grant-in-aid for scientific research (25560416 to M.A.) from the Japan Society for the Promotion of Science and was partially supported by Research Grant for Encouragement of Students, Graduate School of Environmental and Life Science, Okayama University.

\section{REFERENCES}

Allan V. J. (1999) Basic immunofluorescence. In: Protein Localization by Fluorescence Microscopy: A Practical Approach, (Ed. V. J. Allan). Oxford University Press, Oxford, 1-26

Ando M., Shigenaka Y. (1989) Structure and function of the cytoskeleton in heliozoa: I. Mechanism of rapid axopodial contraction in Echinosphaerium. Cell Motil. Cytoskeleton 14: 288-301

Bardele C. F. (1975) The fine structure of the centrohelidian heliozoan Heterophrys marina. Cell Tissue Res. 161: 85-102

Belmont L. D., Hyman A. A., Sawin K. E., Mitchison T. J. (1990) Real-time visualization of cell cycle-dependent changes in microtubule dynamics in cytoplasmic extracts. Cell 62: 579-589

Cassimeris L., Pryer N. K., Salmon E. D. (1988) Real-time observations of microtubule dynamic instability in living cells. J. Cell Biol. 107: 2223-2231

Evangelio J. A., Abal M., Barasoain I., Souto A. A., Lillo M. P., Acuña A. U., Andreu J. M. (1998) Fluorescent taxoids as probes of the microtubule cytoskeleton. Cell Motil. Cytoskeleton 39: 73-90

Febvre-Chevalier C., Bilbaut A., Bone Q., Febvre J. (1986) Sodiumcalcium action potential associated with contraction in the heliozoan Actinocoryne contractilis. J. Exp. Biol. 122: 177-192

Febvre-Chevalier C., Febvre J. (1992) Microtubule dissassembly in vivo: intercalary destabilization and breakdown of microtubules in the heliozoan Actinocoryne contractilis. J. Cell Biol. 118: 585-594

Febvre-Chevalier C., Febvre J. (1993) Structural and physiological basis of axopodial dynamics. Acta Protozool. 32: 211-228

Febvre-Chevalier C., Febvre J. (2001) Heliozoa. In: eLS. John Wiley \& Sons Ltd, Chichester, DOI: 10.1038/npg.els.0002103

Griffiths G. (2012) Preembedding Immuno-Labelling. In: Fine structure immunocytochemistry, (Ed. G. Griffiths). Springer, Heidelberg, 345-370

Gueth-Hallonet C., Antony C., Aghion J., Santa-Maria A., LajoieMazenc I., Wright M., Maro B. (1993) Gamma-tubulin is present in acentriolar MTOCs during early mouse development. $J$. Cell Sci. 105: 157-166

Horio T., Hotani H. (1986) Visualization of the dynamic instability of individual microtubules by dark-field microscopy. Nature 321: 605-607

Karabay A., Korulu Ş., Ünal A. Y. (2012) Immunocytochemistry of Cytoskeleton Proteins. In: Applications of Immunocytochemistry, (Ed. H. Dehghani). Intech Open Access Publisher, Rijeka, 97-1161

Khan S. M. K., Arikawa M., Omura G., Suetomo Y., Kakuta S., Suzaki, T. (2003) Axopodial contraction in the heliozoon Raphidiophrys contractilis requires extracellular $\mathrm{Ca}^{2+}$. Zool. Sci. 20: $1367-1373$

Khan S. M. K., Yoshimura C., Arikawa M., Omura G., Nishiyama, S., Suetomo, Y., Suzaki, T. (2006) Axopodial degradation in the heliozoon Raphidiophrys contractilis: a novel bioassay system for detecting heavy metal toxicity in an aquatic environment. Environ. Sci. 13: 193-200 
Kiernan J. A. (2000) Formaldehyde, formalin, paraformaldehyde and glutaraldehyde: what they are and what they do. Micros. Today 8: 8-13

Kinoshita E., Suzaki T., Shigenaka Y., Sugiyama M. (1995) Ultrastructure and rapid axopodial contraction of a heliozoa, Raphidiophrys contractilis sp. nov. J. Eukaryot. Microbiol. 42: 283-288

Kinoshita E., Shigenaka Y., Suzaki T. (2001) The ultrastructure of contractile tubules in the heliozoon Actinophrys sol and their possible involvement in rapid axopodial contraction. J. Eukaryot. Microbiol. 48: 519-526

Matsuoka T., Shigenaka Y., Naitoh Y. (1985) A model of contractile tubules showing how they contract in the heliozoan Echinosphaerium. Cell Struct. Funct. 10: 63-70

McBeath E., Fujiwara K. (1984) Improved fixation for immunofluorescence microscopy using light-activated 1, 3, 5-triazido-2, 4, 6-trinitrobenzene (TTB). J. Cell Biol. 99: 2061-2073

Moore R. C., Zhang M., Cassimeris L., Cyr R. J. (1997) In vitro assembled plant microtubules exhibit a high state of dynamic instability. Cell Motil. Cytoskeleton 38: 278-286

Ockleford C. D., Tucker J. B. (1973) Growth, breakdown, repair, and rapid contraction of microtubular axopodia in the heliozoan Actinophrys sol. J. Ultrastruct. Res. 44: 369-387

Peknicova J., Pexidrova M., Kubatova A., Koubek P., Tepla O., Sulimenko T., Draber P. (2007) Expression of beta-tubulin epitope in human sperm with pathological spermiogram. Fertil. Steril. 88: 1120-1128

Prigent Y., Kann M. L., Lach-Gar H., Pechart I., Fouquet J. P. (1996) Glutamylated tubulin as a marker of microtubule heterogeneity in the human sperm flagellum. Mol. Hum. Reprod. 2: 573-581

Sakaguchi M., Suzaki T., Khan S. M. K., Hausmann K. (2002) Food capture by kinetocysts in the heliozoon Raphidiophrys contractilis. Eur. J. Protistol. 37: 453-458

Schliwa M., Van Blerkom J. (1981) Structural interaction of cytoskeletal components. J. Cell Biol. 90: 222-235
Smith T. K., Lund E. K., Parker M. L., Clarke R. G., Johnson I. T. (2004) Allyl-isothiocyanate causes mitotic block, loss of cell adhesion and disrupted cytoskeletal structure in HT29 cells. Carcinogenesis 25: 1409-1415

Sudo H., Baas P. W. (2010) Acetylation of microtubules influences their sensitivity to severing by katanin in neurons and fibroblasts. J. Neurosci. 30: 7215-7226

Suzaki T., Ando M., Inai Y., Shigenaka Y. (1994) Structure and function of the cytoskeleton in heliozoa: 3. Rapid microtubule disorganization during axopodial contraction in Echinosphaerium. Eur. J. Protistol. 30: 404-413

Suzaki T., Shigenaka Y., Watanabe S., Toyohara A. (1980) Food capture and ingestion in the large heliozoan, Echinosphaerium nucleofilum. J. Cell Sci. 42: 61-79

Tilney L. G., Hiramoto Y., Marsland D. (1966) Studies on the microtubules in Heliozoa. III. A pressure analysis of the role of these structures in the formation and maintenance of the axopodia of Actinosphaerium nucleofilum (Barrett). J. Cell biol. 29: 77-95

Waters J. C., Chen R. H., Murray A. W., Salmon E. D. (1998) Localization of Mad2 to kinetochores depends on microtubule attachment, not tension. J. Cell Biol. 141: 1181-1191

Watters C. (1968) Studies on the Motility of the Heliozoa: I. The Locomotion of Actinosphaerium Eichhorni and Actinophrys sp. J. Cell Sci. 3: 231-244

Zlatogursky V. V., Drachko D., Klimov V. I., Shishkin, Y. (2018) On the phylogenetic position of the genus Raphidocystis (Haptista: Centroplasthelida) with notes on the dimorphism in centrohelid life cycle. Eur. J. Protistol. 64: 82-90

Received on $21^{\text {st }}$ November, 2019; revised on $31^{\text {st }}$ March, 2020; accepted on $23^{\text {rd }}$ April, 2020 